Research Article

Animal Genetics

\title{
Cytogenetic and genetic data support Crossodactylus aeneus Müller, 1924 as a new junior synonym of C. gaudichaudii Duméril and Bibron, 1841 (Amphibia, Anura)
}

\author{
Stenio Eder Vittorazzi ${ }^{1,2}$ (D), Luciana Bolsoni Lourenço ${ }^{3}$ (D) , Michelle Louise Zattera ${ }^{2}$ (D), \\ Luiz Norberto Weber ${ }^{4}$ (D), Shirlei Maria Recco-Pimentel ${ }^{3}$ (ID) and Daniel Pacheco Bruschi ${ }^{2}$ (C) \\ ${ }^{1}$ Universidade do Estado de Mato Grosso, Faculdade de Ciências Biológicas, Agrárias e da Saúde, \\ Departamento de Ciências Biológicas, Tangará da Serra, MT, Brazil. \\ ${ }^{2}$ Universidade Federal do Paraná, Setor de Ciências Biológicas, Departamento de Genética, Programa de \\ Pós-Graduação em Genética, Curitiba, PR, Brazil. \\ ${ }^{3}$ Universidade Estadual de Campinas, Instituto de Biologia, Departamento de Biologia Estrutural e \\ Funcional, Campinas, SP, Brazil. \\ ${ }^{4}$ Universidade Federal do Sul da Bahia, Instituto Sosígenes Costa de Humanidades, Artes e Ciências, Porto \\ Seguro, BA, Brazil.
}

\begin{abstract}
The nominal anuran species Crossodactylus gaudichaudii Duméril and Bibron, 1841 and Crossodactylus aeneus Müller, 1924 are indistinguishable based on adult and larval morphology, being subject of taxonomic doubts. Here, we describe the karyotypes of $C$. gaudichaudii and $C$. aeneus, using classical and molecular cytogenetic markers. In addition, we used sequences of the $\mathrm{H} 1$ mitochondrial DNA to infer their phylogenetic relationships by Maximum Likelihood (ML) and Maximum Parsimony (MP) approaches and species delimitation test (by bPTP approach). The karyotypic data do not differentiate C. gaudichaudii and C. aeneus in any of the chromosome markers assessed. In both phylogenetic analyses, $C$. gaudichaudii and $C$. aeneus were recovered into a strongly supported clade. The species delimitation analysis recovered the specimens assigned to C. gaudichaudii and C. aeneus as a single taxonomic unit. Taken the cytogenetic and genetic results together with previous studies of internal and external morphology of tadpoles and biacoustic pattern, C. gaudichaudii and C. aeneus could not be differentiated, which supports the hypothesis that they correspond to the same taxonomic unit, with $C$. aeneus being a junior synonym of C. gaudichaudii.
\end{abstract}

Keywords: Crossodactylus, chromosome, karyotype, synonymous species, species delimitation.

Received: August 20, 2020; Accepted: February 08, 2021.

\section{Introduction}

The genus Crossodactylus (Hylodidae) includes 14 species of diurnal frogs that inhabit streams banks, ranging from Alagoas state in northeastern Brazil to Rio Grande do Sul state in southern Brazil, and being found in southern Paraguay and northern Argentina (Carcerelli and Caramaschi, 1993; Frost, 2020). Historically, the taxonomic investigation of the Crossodactylus species has been based on phenotypic features, that is, the external and internal morphology of adults and larvae, bioacoustics, and morphometric parameters (Caramaschi and Sazima, 1985; Pimenta et al., 2014; 2015). Although species of Crossodactylus were included in some molecular phylogenetic inferences (e.g., Pyron and Wiens, 2011; Grant et al., 2017), a phylogenetic analysis focused on this genus remain to be done.

Send correspondence to Stenio Eder Vittorazzi. Universidade do Estado de Mato Grosso, Faculdade de Ciências Biológicas, Agrárias e da Saúde, Departamento de Ciências Biológicas, Rodovia MT-358 (Avenida Inácio Bittencourt Cardoso), Km 07, s/n, Jardim Aeroporto, 78300-000, Caixa Postal 287, Tangará da Serra, MT, Brazil. Email: stenio.vittorazzi@gmail.com.
Based on the morphological and morphometric evidence, Caramaschi and Sazima (1985) recognized three Crossodactylus species groups, the Crossodactylus gaudichaudii, Crossodactylus trachystomus, and Crossodactylus schmidti (monotypic) species groups. However, Pimenta et al. (2014) questioned the validity of the analysis of morphometric characters in this genus, given that many characters overlap extensively between species (except in Crossodactylus grandis). Because of the phenotypic similarities of the Crossodactylus species, more reliable and conclusive taxonomic studies will require the systematic integration of morphological and molecular evidence.

One clear example of this taxonomic dilemma is found in the two species of the $C$. gaudichaudii group, $C$. gaudichaudii and $C$. aeneus, which have overlapping geographic ranges in southeastern Brazil, where they occur predominantly in the states of São Paulo and Rio de Janeiro (Frost, 2020). The original description of $C$. gaudichaudii lacks details on the type locality, which was identified only as "Brazil" (Duméril and Bibron, 1841; Guibé, 1948), although Bokermann (1966) suggested that the city of Rio de Janeiro was the most probable type locality of the species. The type locality of $C$. aeneus is given as "Barreira" in the Serra dos Órgãos range (Müller, 
1924), locality currently belonging to the municipality of Guapimirim, in Rio de Janeiro state, Brazil. The uncertainties with regard to the geographic distribution of these species have been magnified by overlapping bioacoustic parameters (Pimenta et al., 2008, 2015) and both the external (Francioni and Carcerelli, 1993; Silva-Soares et al., 2015) and internal oral morphology of the tadpoles (Weber and Caramaschi, 2006; Silva-Soares et al., 2015). These characters have failed to provide reliable diagnostic traits that confirm their taxonomic status as independent evolutionary lineages (Faivovich, 1998; Weber and Caramaschi, 2006; Silva-Soares et al., 2015).

To answer if $C$. aeneus is a valid species, we aimed to contribute to the assessment of this taxonomic problem comparing $C$. gaudichaudii and $C$. aeneus based on a detailed characterization of their karyotypes and on genetic analyses of H1 mitochondrial DNA sequences (12S+tRNA-val+16S).

\section{Material and Methods}

\section{Crossodactylus aeneus and C. gaudichaudii sampling}

We sampled the type locality of $C$. aeneus and the city of Rio de Janeiro, which is the most probable type locality of $C$. gaudichaudii (see Bokermann, 1966). Three adult $C$. gaudichaudii specimens (ZUEC 17569-17571) were collected from Parque Lage in the Tijuca Forest in the municipality of
Rio de Janeiro, Rio de Janeiro state, Brazil (22॰57’29” S, $43^{\circ} 12^{\prime} 38^{\prime \prime} \mathrm{W}, 129 \mathrm{~m}$ ), and one topotype of C. aeneus (tadpole, ZUEC 20459) was collected from Barreira, near the Soberbo River in the municipality of Guapimirim, Rio de Janeiro state, Brazil (22²9'19” S, 4300'43” W, 582 m).

We also analyzed three adult specimens (ZUEC 1757817580) from the Parque Natural Municipal da Taquara (PNMT) in the municipality of Duque de Caxias, Rio de Janeiro state, Brazil (2235'23' S, 4313'38' W, $241 \mathrm{~m}$ ) (Figure 1). These specimens were compared with specimens from collections (Table S1), original descriptions of $C$. gaudichaudii and $C$. aeneus, and literature information about the species occurrence. PNMT are located on the geographical region named "Serra dos Órgãos", slope of Petrópolis, the same mountain region of the type locality of $C$. aeneus (Figure 1). Hence, because no morphological distinction was noted between the specimens from Duque de Caxias and those from the type locality of C. aeneus or, those specimens used for this species description, we tentatively assigned to $C$. aeneus the specimens from Duque de Caxias.

The collection of specimens was authorized by the Brazilian Institute for the Environment and Renewable Natural Resources (IBAMA - Process number 21619-1). All collected specimens were fixed and deposited in the Museum of Zoology "Professor Adão José Cardoso" of the University of Campinas (ZUEC), in Campinas, São Paulo, Brazil. Details of the location

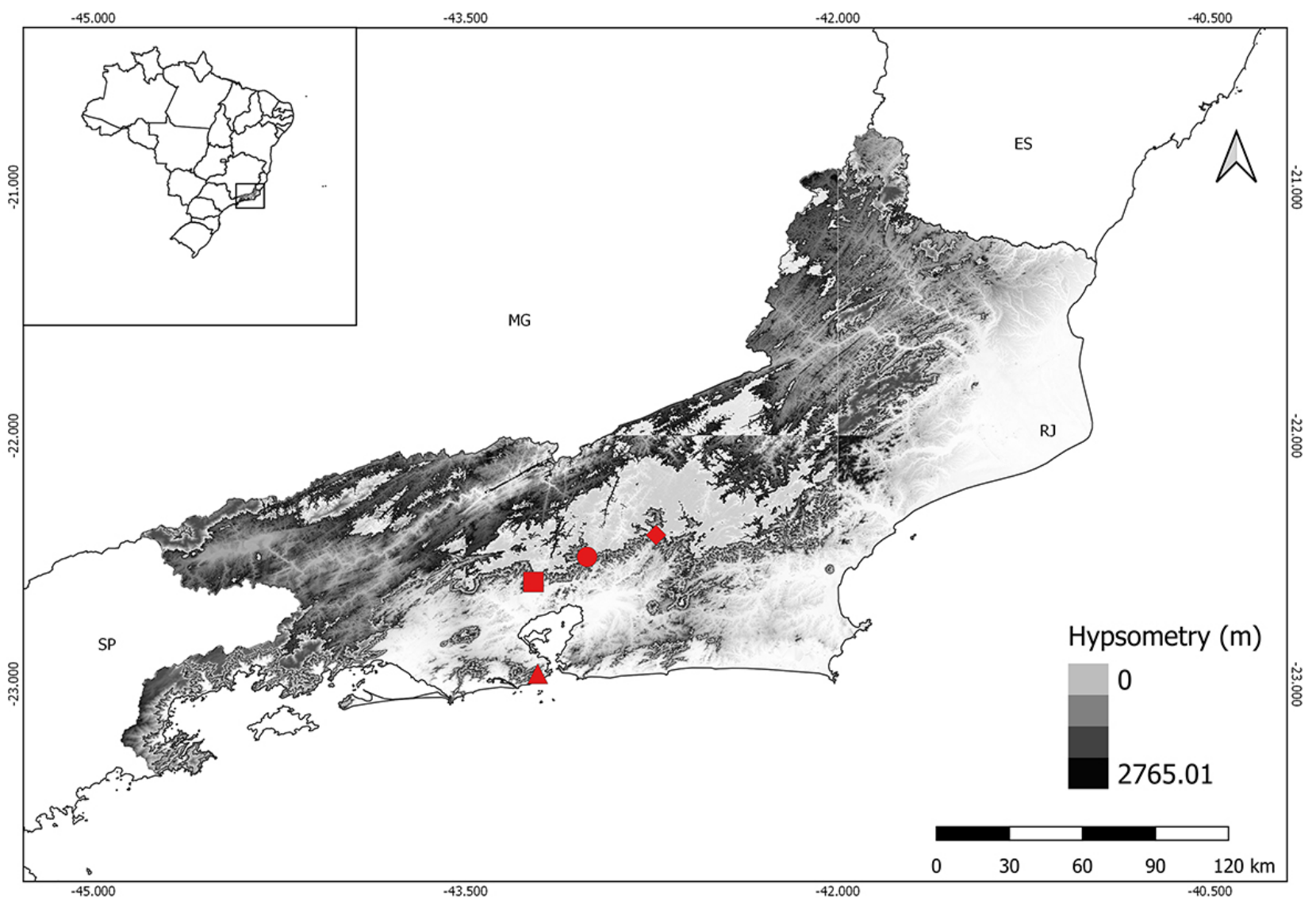

Figure 1 - Localities of the specimens assigned as C. gaudichaudii and C. aeneus analyzed in the present work. $\mathbf{\Delta}$ Crossodactylus gaudichaudii from

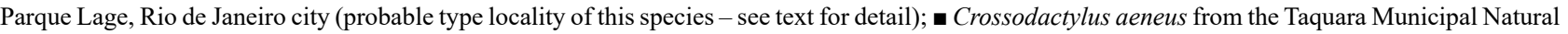
Park (PNMT), municipality of Duque de Caxias; • Crossodactylus aeneus (topotype) from Barreira, municipality of Guapimirim; and $\bullet$ Crossodactylus aeneus from Reserva Ecológica de Guapiaçu, Cachoeiras de Macacu (Amaral et al., 2019). 
and voucher number information is summarized in Table S2. For the analyses described below, tissue samples were extracted from specimens anesthetized with 5\% Lidocaine (applied to the skin), following the recommendations of the Herpetological Animal Care and Use Committee (HACC) of the American Society of Ichthyologists and Herpetologists (available at http//www.asih.org).

\section{Extraction of the DNA}

The genomic DNA was extracted from liver or muscle tissue, previously maintained at $-80{ }^{\circ} \mathrm{C}$, from three $C$. gaudichaudii specimens and four C. aeneus (Table S2). The tissue was lysed in TNES (50 mM Tris- $\mathrm{HCl}, \mathrm{pH} 7.5,400$ $\mathrm{mM} \mathrm{NaCl}, 20 \mathrm{mM}$ EDTA, and 0.5\% SDS) supplemented with proteinase $\mathrm{K}(100 \mu \mathrm{g} / \mathrm{mL})$ at $56{ }^{\circ} \mathrm{C}$ for approximately 3 hours. After lysis, the samples were treated with RNAse (50 $\mu \mathrm{g} / \mathrm{mL}$ ), and $\mathrm{NaCl}$ was added to a final concentration of $\sim 1.7$ $\mathrm{M}$. The DNA was precipitated in isopropyl alcohol, washed in ethanol $(70 \%)$, and rehydrated in TE $(10 \mathrm{mM}$ Tris- $\mathrm{HCl}$, $1 \mathrm{mM}$ EDTA, $\mathrm{pH}$ 8). For quality control and to quantify the genomic DNA, the samples were electrophoresed in $0.8 \%$ agarose gel and analyzed by spectrophotometry.

\section{Mitochondrial DNA sequencing}

To generate data for the genetic distance, phylogenetic, and species delimitation analyses, sequences of the $\mathrm{H} 1$ mitochondrial DNA (that comprise the 12S rRNA, Val-tRNA, and 16S rRNA genes) were obtained by PCR using the primer pairs MVZ 59 (Graybeal, 1997)/Titus I (Titus and Larson, 1996) and 12L13 (Feller and Hedges, 1998)/16Sbr (Palumbi et al., 2002). The amplified products were electrophoresed in $1 \%$ agarose gels and then purified using the GFX PCR and Gel Band DNA Purification kit (GE Healthcare) according to the manufacturer's instructions. The samples were sequenced using the BigDye Terminator kit (Applied Biosystems), with the primers MVZ 59, MVZ 50 (Graybeal, 1997), 12L13 (Feller and Hedges, 1998), Titus I (Titus and Larson, 1996), 16L2a, 16H10 (Hedges, 1994), 16sAR, and 16sBR (Palumbi et al., 2002).

The products of the sequencing reactions were purified by precipitation in $80 \%$ ethanol and centrifugation at 1,200 rpm for 30 minutes, and were then washed in $70 \%$ ethanol and centrifuged for 10 minutes. Once dried, the products were resuspended in loading dye (Blue-Dextran-EDTA/Formamide, 1:5), denatured for 3 minutes at $94{ }^{\circ} \mathrm{C}$, and then transferred to automatic sequencer. The sequences were edited using the Bioedit software, available at http://www.jwbrown.mbio.ncsu. edu/BioEdit/bioedit.html (Hall, 1999).

\section{DNA sequence analyses}

The mitochondrial DNA dataset included sequences from three individuals of C. gaudichaudii and four C. aeneus, and all the $\mathrm{H} 1$ or partial $16 \mathrm{~S}$ gene sequences available in the GenBank for Crossodactylus species (Table S2), including three partial sequences of the $16 \mathrm{~S}$ rRNA gene of $C$. aeneus from Reserva Ecológica de Guapiaçu, Cachoeiras de Macacu, Rio de Janeiro, Brazil (Amaral et al., 2019; Figure 1). Therefore, we included sequences of $C$. aeneus, C. caramaschii ( $C$. gaudichaudii species group), $C$. werneri ( $C$. dispar species complex), C. trachystomus (C. trachystomus species group), and $C$. schmidti (C. schmidti species group). We also included Megaelosia goeldii and Hylodes phylodes as representatives of the two other genera comprised in the Hylodidae family, and representatives of Alsodidae, which has been inferred as the sister group of Hylodidae (Pyron and Wiens, 2011; Grant et al., 2017) (for details, see Table S2). The dataset was aligned using the MAFFT v7 application (Katoh et al., 2019) and generated a matrix composed of the 2,369 bp.

The phylogenetic analyses were based on the Maximum Likelihood (ML) and Maximum Parsimony (MP) approaches. For the ML analysis, the GTR substitution model was inferred by MrModeltest v2.3 (Nylander, 2004) as the best model of evolution. The unpartitioned DNA matrix sequence was implemented in RAxML (Kozlov et al., 2019) with estimate stationary base frequencies, executing 10 separate searches with different starting trees. The bootstrap analysis was performed using 100 replicates to assess the statistical support of clades. The MP analyses were conducted in TNT v1.5 (Goloboff and Catalano, 2016) using the new technology search option (the best length was hit 100 times), including sectorial searches, ratchet, tree drifting, and tree fusing. The gaps were considered as fifth state and support of the edges was evaluated by bootstrap analysis with 1,000 replicates.

Uncorrected p-distances among and within clades of interest were calculated using MEGA X (Kumar et al., 2018). This analysis was conducted with the mitochondrial $\mathrm{H} 1$ and also with the partial fragments of the 16S rRNA gene. Gaps and missing data were deleted in pairwise comparisons.

To assess the taxonomic status of $C$. gaudichaudii and C. aeneus, we used the cladogram inferred in the RAxML analysis to employ a tree-based species delimitation test, using the Poisson Tree Process (PTP) model (Zhang et al., 2013). We used the bPTP version of the PTP method, available on the webserver (http://species.h-its.org/ptp/). The bPTP analysis was run with all parameters set at default except the MCMC, which was set at 500,000 generations. The outgroup was removed to improve the delimitation results as suggest by server.

\section{Classical cytogenetic preparations}

Mitotic metaphases were obtained from cell suspensions of the intestinal epithelium from three $C$. gaudichaudii specimens and four $C$. aeneus (Table $\mathrm{S} 2$ ) previously treated with colchicine (King and Rofe, 1976, with modifications from Gatto et al., 2018). The chromosomes were stained with Giemsa (10\%) and then C-banded (King, 1980). The slides were processed using the Ag-NOR method (Howell and Black, 1980) to detect the Nucleolus Organizer Regions (NORs). The metaphasic chromosomes were photographed under an Olympus BX-60 microscope and classified according to Green and Sessions (1991).

\section{Fluorescent in situ hybridization (FISH)}

The FISH experiments were carried out on specimens ZUEC 17569 and ZUEC 17579 (Table S2), which represent the populations of Rio de Janeiro and Duque de Caxias, respectively. The PcP190 satellite DNA sequence previously isolated from C. gaudichaudii by Vittorazzi et al. (2014) was 
amplified to obtain chromosomal probes. For this, one cloned fragment was amplified by PCR in the presence of digoxigenindUTP (Roche) and primers T7 and SP6, which flank the connection site of the pGEM-T Easy Vector (Promega). The probes were mixed with salmon DNA ( $1 \mathrm{ng} / \mu \mathrm{L}$ of probe) and precipitated in ethanol. The DNA was dissolved in a hybridization buffer at $\mathrm{pH} 7$ composed of deionized formamide (50\%), 2 x SSC, phosphate buffer (40 mM), Denhardt's solution, SDS (1\%), and dextran sulfate (10\%). The in situ hybridization technique was based on Viegas-Péquignot (1992), with modifications for the detection of digoxigeninlabeled probes with anti-DIG-Rhodamine (Roche).

The microsatellites (CA) ${ }_{15}$ and (GATA) $)_{8}$ oligonucleotides were marked directly with Cy5-fluorochrome at the 5' end during synthesis (Sigma-Aldrich) and used as probes in FISH assays that followed the protocol of Kubat et al. (2008), under high stringency $(77 \%)$ conditions. Images of the hybridized metaphase chromosomes were captured with an Olympus BX60 microscope and edited with the Image-Pro Plus program (Media Cybernetics).

\section{Results}

\section{Phylogenetic inferences and species delimitation based on mitochondrial DNA sequences}

All Crossodactylus species were recovered into one strongly supported sister-clade of Hylodes phyllodes + Megaelosia goeldii in the ML and MP analyses. The species C. werneri, C. trachystomus, C. caramaschii and C. schmidti formed the sister-group of a clade composed of $C$. gaudichaudii and $C$. aeneus, however, with low bootstrap support (Figure 2 and Figure S1).

The clade containing $C$. gaudichaudii and C. aeneus was strongly supported in both analyses. The $C$. gaudichaudii specimens (from Rio de Janeiro city) and those specimens of $C$. aeneus from Guapimirim and Cachoeiras de Macacu formed two distinctive groups in both phylogenetic inferences; however, the relationships of $C$. aeneus from Duque de Caxias differed in both analyses. In the ML analysis, the three $C$. aeneus specimens from Duque de Caxias were grouped together with those three $C$. gaudichaudii specimens, however,

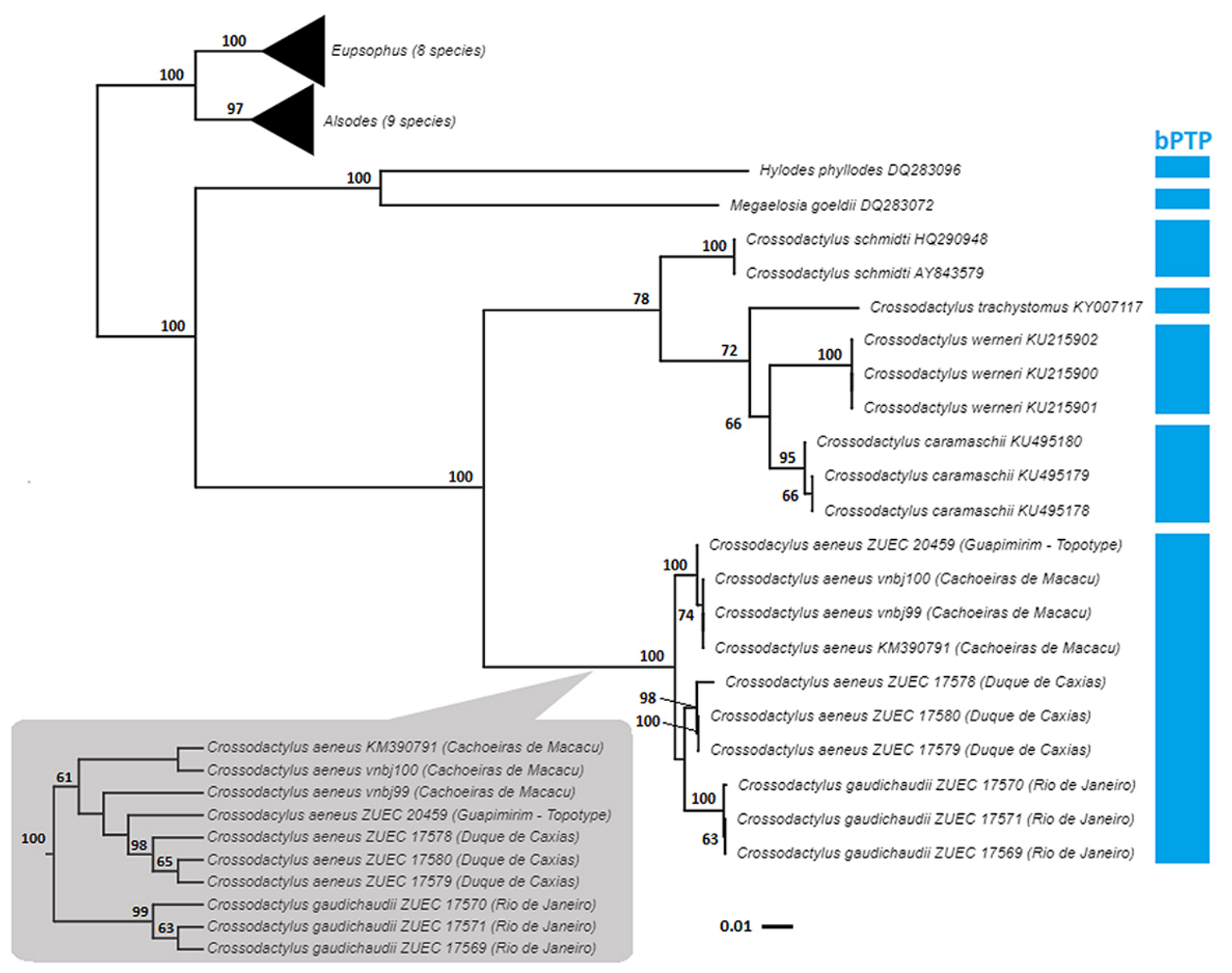

Figure 2 - Phylogenetic relationships among the Crossodactylus species analyzed in the present study, inferred by maximum likelihood analysis of a 2,369-bp H1 mitochondrial DNA sequence matrix. The gray box shows the clade of $C$. gaudichaudii and $C$. aeneus obtained in the Maximum Parsimony analysis. Note the incongruence recovered to the specimens from Duque de Caxias (for complete tree, see Figure S1). The numbers at each node indicate the bootstrap values (values below 50 have been omitted). The blue blocks indicate the partitions recovered by the bPTP analysis of the Crossodactylus specimens. 
without bootstrap support (Figure 2). In contrast, in the MP analysis, C. aeneus was recovered as monophyletic, with all the specimens assigned to this species clustered together in a low supported clade ( $61 \%$ of bootstrap - Figure 2$)$.

The genetic distances between $C$. gaudichaudii and C. aeneus were low, with average uncorrected p-distance of $1.7 \%$ to the partial $16 \mathrm{~S}$ (minimum $1.5 \%$ and maximum $1.9 \%$ ) and $2 \%$ to $\mathrm{H} 1$ sequence (minimum $1.8 \%$ and maximum $2.3 \%$ ) (average values in Table 1). Genetic distances within $C$. aeneus ranged from $0 \%$ to $0.8 \%$ in $16 \mathrm{~S}$ sequence while within the $C$. gaudichaudii population ranged from $0 \%$ to $0.1 \%$ in $16 \mathrm{~S}$ sequences. As the specimens of $C$. aeneus from Duque de Caxias grouped differently in the ML and MP analyses, we also considered these specimens separately in additional comparisons. In $16 \mathrm{~S}$ sequences, the specimens from Duque de Caxias differed from the remaining $C$. aeneus specimens in $0.8 \%$, and from $C$. gaudichaudii in $1.5 \%$. The average genetic distance of $C$. gaudichaudii and $C$. aeneus against the other species included in the analysis $(C$. werneri, C. trachystomus, C. caramaschii and C. schmidti) ranged from $7.4 \%$ to $10.7 \%$ in $16 \mathrm{~S}$ sequences (Table 1).

The bPTP species delimitation method recognized $C$. caramaschii, C. trachystomus, C. werneri and C. schmidti as independent taxonomic units, which reinforces the capacity of this procedure to delimit species of Crossodactylus (Figure 2). In addition, the bPTP approach recovered $C$. gaudichaudii and $C$. aeneus as a single partition, with a Bayesian support of 0.94 , supporting the hypothesis that the specimens assigned to these species belong to a single species (Figure 2).

\section{Cytogenetic analysis}

The specimens assigned to both $C$. gaudichaudii and C. aeneus had a diploid number of $2 \mathrm{n}=26$ chromosomes, with a karyotype composed of six metacentric pairs $(1,4,9$, 11-13), five submetacentric pairs (2, 6-8 and 10), and two subtelocentric pairs (pairs 3 and 5) (Figure 3a, f). An extensive

Table 1 - Uncorrected p-distances (in percentage) based on partial 16S rDNA (bottom triangle) and H1 mitochondrial DNA (top triangle) of the Crossodactylus species analyzed in the present study. Gray cells show intraspecific variation of the partial 16S rDNA (left) and H1 mitochondrial DNA (right).

\begin{tabular}{|c|c|c|c|c|c|c|c|c|}
\hline Species & 1 & 2 & 3 & 4 & 5 & 6 & 7 & 8 \\
\hline 1. C. aeneus (Guapimirim - Topotype) & $-/-$ & 1.6 & - & 2 & 10.4 & - & - & - \\
\hline 2. C. aeneus (Duque de Caxias) & 0.7 & $0 / 0.5$ & - & 2 & 10.4 & - & - & - \\
\hline 3. C. aeneus (Cachoeiras de Macacu) & 0.1 & 0.8 & $0.1 /-$ & - & - & - & - & - \\
\hline 4. C. gaudichaudii (Rio de Janeiro city) & 1.7 & 1.5 & 1.8 & $0 / 0.1$ & 10.2 & - & - & - \\
\hline 5. C. schmidti & 7.4 & 7.6 & 7.6 & 7.4 & $0 / 0$ & - & - & - \\
\hline 6. C. trachystomus & 8.6 & 8.2 & 8.6 & 8.2 & 6.7 & $-/-$ & - & - \\
\hline 7. C. caramaschii & 9.2 & 8.7 & 9.2 & 7.4 & 6.8 & 6.4 & $0.2 /-$ & - \\
\hline 8. C. werneri & 10.5 & 10.7 & 10.4 & 9.6 & 6.3 & 6.5 & 5.6 & $0 /-$ \\
\hline
\end{tabular}

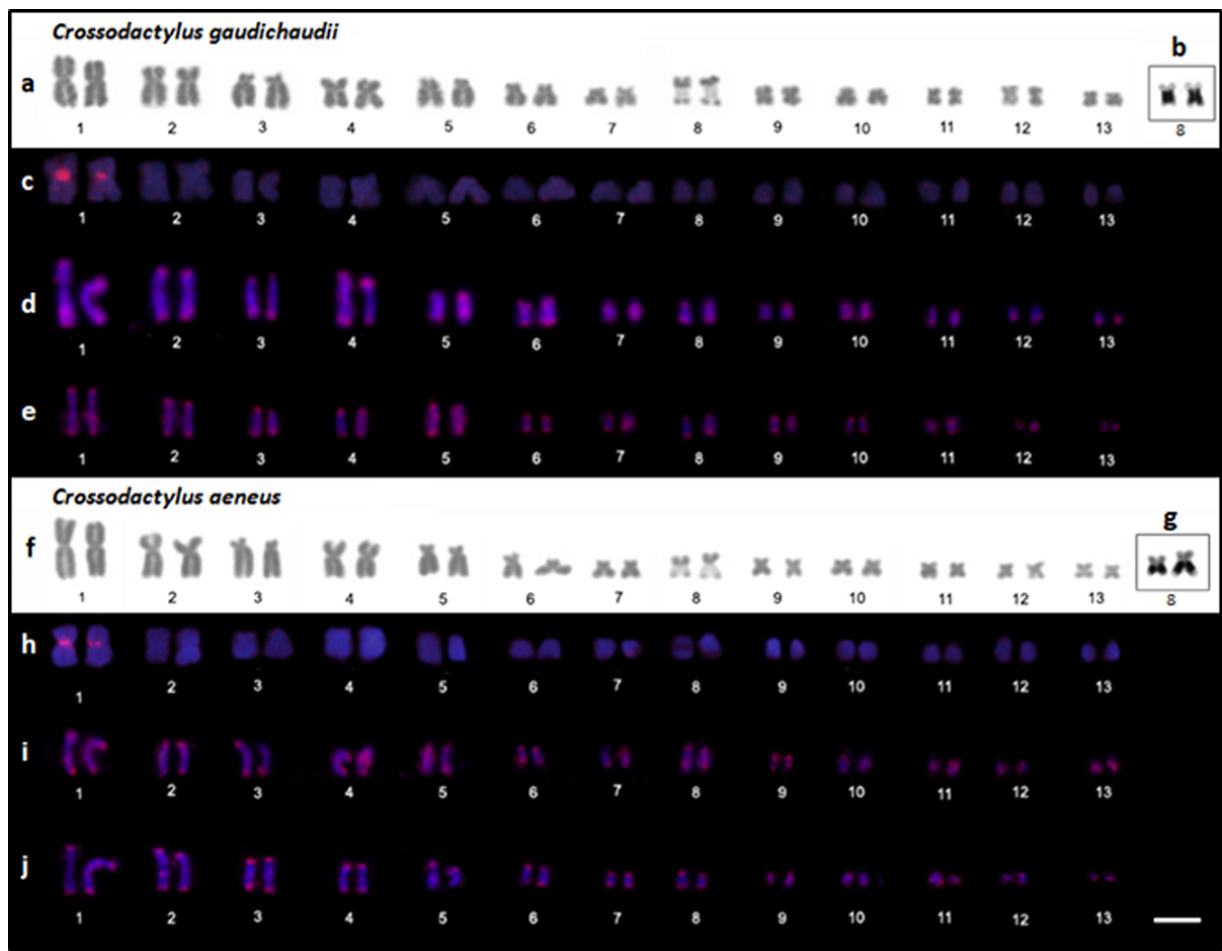

Figure 3 - Karyotypes of C. gaudichaudii and C. aeneus. Chromosomes stained with Giemsa (a, f); The secondary constrictions in the long arm of pair 8 coincide with the NOR, which were silver-impregnated by the Ag-NOR method, as shown in insets b and $g$. Dark planks show chromosome hybridized with probes for the PcP190 satellite DNA $(c, h),(C A)_{15}$ microsatellite repeat $(\mathrm{d}, \mathrm{i})$, and (GATA) ${ }_{8}$ microsatellite repeat in $(\mathrm{e}, \mathrm{j})$. Bar $=10 \mu \mathrm{m}$. 
secondary constriction was observed in the long arm of the homologs of pair 8 in some metaphases, which coincides with NOR. On the other hand, smaller secondary constrictions were also seen and consequently, in these cases, the NOR-bearing chromosome pair could be classified as pair 8 according to its size. Therefore, despite a secondary constriction increased the chromosome size in most metaphases, we classified the NORbearing chromosome pair as pair 8 to reflect our hypothesis of chromosomal homology when we compare the karyotypes described here with karyotypes previously described to other Crossodactylus species (Beçak, 1968; De Lucca et al., 1974; Aguiar-Jr et al., 2004; Amaro, 2005). The C-banding technique detected a weak centromeric heterochromatin signal in some of the chromosome pairs of both karyotypes. As the C-banding data were insufficient for discussion, we show these results in Figure S2.

A conspicuous PcP190 satellite DNA cluster was found in the centromeric region of the homologs of pair 1 in both species (Figure 3c, h), while the mapping of the microsatellite repeats $(\mathrm{CA})_{15}$ (Figure $\left.3 \mathrm{~d}, \mathrm{i}\right)$ and (GATA) ${ }_{8}$ (Figure 3e,j) revealed hybridization signals in the terminal regions of all the chromosomes in all the specimens assigned to both $C$. gaudichaudii and C. aeneus.

\section{Discussion}

Chromosomal analysis of $C$. gaudichaudii and C. aeneus showed the same diploid (2n) and fundamental (FN) numbers previously reported to C. caramaschii (Aguiar-Jr et al., 2004; Amaro, 2005), C. dispar (De Lucca et al., 1974), C. grandis (Beçak, 1968) and C. schmidti (Amaro, 2005), suggesting an overall similarity among the Crossodactylus karyotypes. The NOR located in a small-sized biarmed chromosome pair is a common feature within Crossodactylus species, as NORs were detected on the long arm of pair 8 in karyotypes of $C$. caramaschii (Aguiar-Jr et al., 2004), C. schmidti (Amaro, 2005), C. gaudichaudii, and C. aeneus (present study).

Cytogenetic data have provided important insights into interspecific comparisons in many groups, helping in evolutionary analyses. In cytogenetic studies of anurans, the NOR has been used as a valuable chromosome marker for the differentiation of species (Schmid et al., 2014) and even populations (Silva et al., 1999; Quinderé et al., 2009; Nascimento et al., 2019), although in several cases, the location of the NOR varies little among closely-related species (Busin et al., 2008; Cardozo et al., 2011). When we compared the karyotypes of $C$. gaudichaudii and C. aeneus based on diploid number, FN, NOR location, mapping of PcP190 satellite DNA and mapping of (CA) ${ }_{15}$ and (GATA) microsatellite clusters, no differences were found. Therefore, the cytogenetic traits described here to $C$. gaudichaudii and C. aeneus provide insufficient evidence for the differentiation of these two species.

The PcP190 satellite DNA was first described in the anuran Physalaemus cuvieri (Vittorazzi et al., 2011), and this satellite DNA family was subsequently detected in a number of anuran species, with a species-specific sequence variant being found in $C$. gaudichaudii (Vittorazzi et al., 2014). The data available on the PcP190 indicate that this satellite DNA family is a valuable chromosomal marker for karyotypic comparisons of the anurans. The chromosomal hybridization of PcP190 markers has revealed major interspecific differences in closely-related Physalaemus species, and differentiated the karyotypes of at least three $P$. cuvieri populations (Vittorazzi et al., 2014), later pointed as species (Lourenço et al., 2015). In the present analysis of $C$. gaudichaudii and $C$. aeneus, however, no clear differentiation of the karyotypes was found.

The chromosomes of $C$. gaudichaudii and C. aeneus present an accumulation of each analyzed microsatellite motifs, primarily in the subterminal regions of both arms, a pattern observed in the karyotype of a number of other anuran species (Peixoto et al., 2015, 2016; Ernetti et al., 2019). The enrichment of microsatellites in subterminal chromosomal regions may play a fundamental role in the stabilization and function of these regions in the eukaryotic chromosome (Buschiazzo and Gemmell, 2006; Richard et al., 2008; Torres et al., 2011), and has been found in several different vertebrate groups (Cioffi et al., 2011; Ruiz-Ruano et al., 2015; Peixoto et al., 2015, 2016; Oliveira et al., 2017).

The phylogenetic analyses based on the mitochondrial H1 fragment clustered all the specimens assigned to $C$. gaudichaudii and $C$. aeneus in a highly supported monophyletic group, which is the sister-clade of the C. trachystomus $+C$. caramaschii $+C$. schmidti $+C$. werneri clade. The $C$. aeneus specimens from Duque de Caxias, which is located in the same mountain range as the type locality of $C$. aeneus, clustered with a topotype of $C$. aeneus in the MP analysis, whereas they were grouped together with specimens of $C$. gaudichaudii in the ML analysis. Such uncertainty about the relationships of these specimens reinforces the taxonomic issues concerning C. gaudichaudii and C. aeneus. In addition, it agrees with the bPTP analysis, which assembled all the specimens assigned to $C$. gaudichaudii and C. aeneus in the same partition, as belonging to a single species. The genetic distance analysis was also congruent with these previous inferences, as low genetic divergence was found between specimens assigned to C. gaudichaudii and C. aeneus. While the genetic distances between $C$. gaudichaudii and C. aeneus ranged from 1.5\% to $1.9 \%$ in the partial $16 \mathrm{~S}$ rRNA gene, the other pairs of Crossodactylus species analyzed here varied between $7.4 \%$ and $10.7 \%$, reflecting high levels of genetic diversification among valid species of this genus. These genetic distances estimated between $C$. gaudichaudii and $C$. aeneus were also below the threshold of 3\% proposed by Fouquet et al. (2007) and Lyra et al. (2017) to flag candidate species based on this gene marker. Therefore, the genetic divergence among the specimens assigned to $C$. gaudichaudii and $C$. aeneus could represent population structure rather than interspecific variation.

In the past, other nomen had been synonymized with $C$. gaudichaudii (Limnocharis fuscus Bell, 1843; Elosia vomerina Girard, 1853; Phyllobates brasiliensis De Witte, 1830). Here, taken the cytogenetic and genetic results together with previous studies of internal and external morphology of tadpoles (Francioni and Carcerelli, 1993; Weber and Caramaschi, 2006; Silva-Soares et al., 2015) and biacoustic pattern (Pimenta et al., 2015), we notice that $C$. gaudichaudii and C. aeneus could not be differentiated, which supports the hypothesis that they correspond to the same taxonomic unit, with $C$. aeneus being a new junior synonym of $C$. gaudichaudii. 


\section{Acknowledgments}

We thank Universidade Federal do Paraná and Universidade Federal do Sul da Bahia to financial support (Process n ${ }^{\circ} 23075.044632 / 2019-25$ and 23746.005146/2020-91, respectively). We thank the Coordenação de Aperfeiçoamento de Pessoal de Nível Superior (CAPES/PROAP - Finance Code 001) for the scholarships provided to MLZ. We thank the Multi-User Confocal Microscopy Center of the Federal University of Paraná for the capture of the images included in this study.

\section{Conflict of Interest}

The authors declare that they have no conflict of interest.

\section{Author Contributions}

SEV designed the study, conducted the experiments, carried out the analyses and drafted the manuscript. MLZ conducted the experiments and revised the manuscript. LNW raised the issue of species, collected and identified the specimens and revised the manuscript. LBL, SMRP and DPB coordinated the study and revised the manuscript. All authors approved the final version of the present study.

\section{References}

Aguiar-Jr O, Carvalho KA, Giaretta AA and Recco-Pimentel SM (2004) Cytogenetics of Hylodes and Crossodactylus species (Anura, Leptodactylidae) with comments on Hylodinae/ Dendrobatid relationships. Genetica 121:43-53.

Amaral C, Chaves A, Borges JV, Pereira F, Silva BM, Silva DA, Amorim A, Carvalho EF and Rocha C (2019) Amphibians on the hotspot: Molecular biology and conservation in the South American Atlantic Rainforest. PLoS One 14(10):e00224320.

Amaro RC (2005) Caracterização citogenética de espécies de Bufo e Leptodactylus (Amphibia, Anura), utilizando coloração diferencial e hibridação in situ fluorescente. M. Sc. Thesis, Universidade de São Paulo, São Paulo.

Beçak ML (1968) Chromosomal analysis of eighteen species of Anura. Caryologia 21:191-208.

Bokermann WCA (1966) Lista anotada das localidades tipo de anfíbios brasileiros. Serviço de Documentação da Universidade de São Paulo, São Paulo, 181 pp.

Buschiazzo E and Gemmell NJ (2006) The rise, fall and renaissance of microsatellites in eukaryotic genomes. BioEssays 28:10401050.

Busin CS, Andrade GV, Bertoldo J, Del Grande ML, Uetanabaro M and Recco-Pimentel SM (2008) Cytogenetic analysis of four species of Pseudis (Anura, Hylidae), with the description of ZZ/ ZW sex chromosomes in P. tocantins. Genetica 133:119-127.

Caramaschi U and Sazima I (1985) Uma nova espécie de Crosso dactylus da Serra do Cipó, Minas Gerais, Brasil (Amphibia, Leptodactylidae). Rev Bras Zool 3:43-49.

Carcerelli LC and Caramaschi U (1993) Ocorrência do gênero Crossodactylus Duméril \& Bibron, 1841 no nordeste brasileiro, com descrição de duas espécies novas (Amphibia, Anura, Leptodactylidae). Rev Bras Biol 52:415-422.

Cardozo DE, Leme DM, Bortoleto JF, Catroli GF, Baldo D, Faivovich F, Kolenc F, Silva APZ, Borteiro C, Haddad CFB and Kasahara S (2011) Karyotypic data on 28 species of Scinax (Amphibia: Anura: Hylidae): Diversity and informative variation. Copeia 2:251-263.
Cioffi MB, Kejnovsky E and Bertollo LAC (2011) The chromosomal distribution of microsatellite repeats in the genome of the wolf fish Hoplias malabaricus, focusing on the sex chromosomes. Cytogenet Genome Res 132:289-296.

De Lucca EJ, Jim J and Foresti F (1974) Chromosomal studies in twelve species of Leptodactylidae and one Brachycephalidae. Caryologia 27:183-191.

Duméril AMC and Bibron G (1841) Erpétologie Genérale ou Histoire Naturelle Complète des Reptiles. Librarie Enclyclopedique de Roret, Paris, pp 1834-1854.

Ernetti JR, Gazolla CB, Recco-Pimentel SM, Luca EM and Bruschi DP (2019) Non-random distribution of microsatellite motifs and (TTAGGG)n repeats in the monkey frog Pithecopus rusticus (Anura, Phyllomedusidae) karyotype. Genet Mol Biol 42:e20190151.

Faivovich J (1998) Comments on the larvae of the Argentine species of the genus Crossodactylus (Leptodactylidae, Hylodinae). Alytes 16:61-67.

Feller A and Hedges SB (1998) Molecular evidence for the early history of living amphibians. Mol Phylogenetics Evol 9:509516.

Fouquet A, Gilles A, Vences M, Marty C, Blanc M and Gemmell NJ (2007) Underestimation of species richness in neotropical frogs revealed by mtDNA analyses. PLoS One 2:e1109.

Francioni E and Carcerelli LC (1993) Descrição do girino de Crossodactylus gaudichaudii Duméril \& Bibron, 1841 (Anura, Leptodactylidae). Mem Inst Butantan 55:63-67.

Gatto KP, Mattos JV, Seger KR and Lourenço LB (2018) Sex chromosome differentiation in the frog genus Pseudis involves satellite DNA and chromosome rearrangements. Front Genet 7(9):301.

Goloboff PA and Catalano SA (2016) TNT version 1.5, including a full implementation of phylogenetic morphometrics. Cladistics 32:221-238.

Grant T, Rada M, Anganoy-Criollo M, Batista A, Dias PH, Jeckel AM, Machado DJ and Rueda-Almonacid JV (2017) Phylogenetic systematics of dart-poison frogs and their relatives revisited (Anura: Dendrobatoidea). South Am J Herpetol 12:1-90.

Graybeal A (1997) Phylogenetic relationships of bufonid frogs and tests of alternate macroevolutionary hypotheses characterizing their radiation. Zool J Linn Soc 119:297-338.

Green DM and Sessions SK (1991) Nomenclature for chromosomes. In: Green DM and Sessions SK (eds) Amphibian Cytogenetics and Evolution. Academic Press, San Diego, pp 431-432.

Guibé J (1948) Catalogue des Types d'Amphibiens du Muséum National d'Histoire Naturelle. Imprimerie Nationale, Paris.

Hall TA (1999) BioEdit: a user-friendly biological sequence alignment editor and analysis program for Windows 95/98/NT. Nucleic Acids Symp Ser 41:95-98.

Hedges SB (1994) Molecular evidence for the origin of birds. P Natl Acad Sci U S A 91:2621-2624.

Howell WM and Black DA (1980) Controlled silver staining of nucleolus organizer regions with a protective colloidal developer: a 1-step method. Experientia 36:1014-1015.

Katoh K, Rozewicki J and Yamada KD (2019) MAFFT online service: multiple sequence alignment, interactive sequence choice and visualization. Brief Bioinform 20:1160-1166.

King M and Rofe R (1976) Karyotypic variation in the Australian gekko Phyllodactylus marmoratus (Gray) (Gekkonidae: Reptilia). Chromosoma 54:75-87.

King M (1980) C-banding studies on Australian hylid frogs: secondary constriction structure and the concept of euchromatin transformation. Chromosoma 80:191-217. 
Kozlov A, Darriba D, Flouri T, Morel B and Stamatakis A (2019) RAxML-NG: A fast, scalable, and user-friendly tool for maximum likelihood phylogenetic inference. Bioinformatics 35:4453-4455.

Kubat Z, Hobza R, Vyskot B and Kejnovsky E (2008) Microsatellite accumulation on the $\mathrm{Y}$ chromosome in Silene latifolia. Genome 51:350-356.

Kumar S, Stecher G, Li M, Knyaz C and Tamura K (2018) MEGA $\mathrm{X}$ : Molecular evolutionary genetics analysis across computing platforms. Mol Biol Evol 35:1547-1549.

Lyra ML, Haddad CFB and De Azeredo-Espin AML (2017) Meeting the challenge of DNA barcoding Neotropical amphibians: polymerase chain reaction optimization and new COI primers. Mol Ecol Resour 17:966-980.

Lourenço LB, Targueta CP, Baldo D, Nascimento J, Garcia PCA, Andrade GV, Haddad CFB, and Recco-Pimentel SM (2015) Phylogeny of frogs from the genus Physalaemus (Anura, Leptodactylidae) inferred from mitochondrial and nuclear gene sequences. Mol Phylogenetics Evol 92:204-216.

Müller L (1924) Neue Batrachier aus Ost-Brasilien. Senckenbergiana Biologica 6:169-177.

Nascimento J, Lima JD, Suárez P, Baldo D, Andrade GV, Pierson TW, Fitzpatrick BM, Haddad CFB, Recco-Pimentel SM and Lourenço LB (2019) Extensive cryptic diversity within the Physalaemus cuvieri-Physalaemus ephippifer species complex (Amphibia, Anura) Revealed by Cytogenetic, Mitochondrial, and Genomic Markers. Front Genet 10:719.

Nylander JAA (2004) MrModeltest Version 2. Program distributed by the author. Evolutionary Biology Centre, Uppsala University, Uppsala.

Oliveira TD, Kretschmer R, Bertocchi NA, Degrandi TM, de Oliveira EHC, Cioffi MdB, del Valle Garnero A and Gunski RJ (2017) Genomic organization of repetitive DNA in woodpeckers (Aves, Piciformes): implications for karyotype and ZW sex chromosome differentiation. PLoS One 12:e169987

Palumbi S, Martin A, Romano S, Mcmillan WO, Stice L and Grabowski G (2002) The simple fool's guide to PCR, version 2.0. Department of Zoology and Kewalo Marine Laboratory, University of Hawaii, Honolulu, $45 \mathrm{p}$.

Peixoto M, Lacerda JV, Coelho-Augusto C, Feio R and Dergam J (2015) The karyotypes of five species of the Scinax perpusillus group (Amphibia, Anura, Hylidae) of southeastern Brazil show high levels of chromosomal stabilization in this taxon. Genetica 143:729-739.

Peixoto M, Oliveira M, Feio R and Dergam J (2016) Karyological study of Ololygon tripui (Lourenço, Nascimento and Pires, 2009), (Anura, Hylidae) with comments on chromosomal traits among populations. Comp Cytogenet 10:505-516.

Pimenta BVS, Wachlevski M and Cruz CAG (2008) Morphological and acoustical variation, geographic distribution, and conservation status of the Spinythumb Frog Crossodactylus bokermanni Caramaschi and Sazima, 1985 (Anura, Hylodidae). J Herpetol 42:481-492.

Pimenta BVS, Cruz CAG and Caramaschi U (2014) Taxonomic review of the species complex of Crossodactylus dispar A. Lutz, 1925 (Anura, Hylodidae). Arq Zool 45:1-33.

Pimenta BVS, Caramaschi U and Cruz CAG (2015) Synonymy of Crossodactylus bokermanni Caramaschi \& Sazima, 1985 with Crossodactylus trachystomus (Reinhardt \& Lütken, 1862) and description of a new species from Minas Gerais, Brazil (Anura: Hylodidae). Zootaxa 3955:65-82.
Pyron RA and Wiens JJ (2011) A large-scale phylogeny of Amphibia including over 2,800 species, and a revised classification of extant frogs, salamanders, and caecilians. Mol Phylogenetics Evol 61:543-583.

Quinderé YRSD, Lourenço LB, Andrade GV, Tomatis C, Baldo D and Recco-Pimentel SM (2009) Additional cytogenetics analyses of the widespread anuran Physalaemus cuvieri (Anura, Leiuperidae) with emphasis on NOR variability. Biol Res 42:79-92.

Richard GF, Kerrest A and Dujon B (2008) Comparative genomics and molecular dynamics of DNA repeats in eukaryotes. Microbiol Mol Biol Rev 72:686-727.

Ruiz-Ruano FJ, Cuadrado Á, Montiel EE, Camacho JPM and LópezLéon MD (2015) Next generation sequencing and FISH reveal uneven and nonrandom microsatellite distribution in two grasshopper genomes. Chromosoma 124:221-234.

Schmid M, Steinlein C, Feichtinger W and Bogart JP (2014) Chromosome banding in Amphibia. XXXI. The neotropical anuran families Centrolenidae and Allophrynidae. Cytogenet Genome Res 142:268-285.

Silva APZ, Haddad CFB and Kasahara S (1999) Nucleolus organizer regions in Physalaemus cuvieri (Anura, Leptodactylidae), with evidence of a unique case of Ag-NOR variability. Hereditas 131:135-141.

Silva-Soares T, Costa P, Borges JV, Weber L and Rocha C (2015) The larva of Crossodactylus aeneus Müller, 1924: Morphology and ecological aspects. Herpetologica 71:46-57.

Titus TA and Larson A (1996) Molecular phylogenetics of Desmognathine salamanders (Caudata: Plethodontidae): A reevaluation of evolution in ecology, life history, and morphology. Syst Biol 45:229-238.

Torres GA, Novák P, Bryan GJ, Hirsch CD, Gong Z, Buell CR, Iovene M, Macas J and Jiang J (2011) Organization and evolution of subtelomeric Satellite repeats in the potato genome. G3 (Bethesda) 1:85-82.

Viegas-Péquignot E (1992) In situ hybridization to chromosomes with biotinylated probes. In: Willernson D (ed) In situ hybridization: a pratical approach. Oxford University Press, Oxford, pp 137-158.

Vittorazzi SE, Lourenço LB, Del-Grande ML and Recco-Pimentel SM (2011) Satellite DNA derived from 5S rDNA in Physalaemus cuvieri (Anura, Leiuperidae). Cytogenet Genome Res 134:101107.

Vittorazzi SE, Lourenço LB and Recco-Pimentel SM (2014) Long-time evolution and highly dynamic satellite DNA in leptodactylid and hylodid frogs. BMC Genet 15:111.

Weber LN and Caramaschi U (2006) Descrição da morfologia oral interna de larvas do gênero Crossodactylus Duméril \& Bibron, 1841 (Amphibia, Anura, Leptodactylidae). Arq Mus Nac Rio de Janeiro 64:141-149.

Zhang J, Kapli P, Pavlidis P and Stamatakis A (2013) A general species delimitation method with applications to phylogenetic placements. Bioinformatics 29:2869-2876.

\section{Internet Resources}

Frost D (2020) Amphibian Species of the World: an online reference. Version 6.1 Electronic Database, http://research. amnh.org/herpetology/amphibia/index.html. American Museum of Natural History, New York, (accessed 17 August 2020). 


\section{Supplementary material}

The following online material is available for this article:

Table S1 - Specimens of the Crossodactylus examined in collections to identify the specimens analyzed in the present work.

Table S2 - Specimens included in our analysis.

Figure S1 - Phylogenetic relationships inferred by Maximum Parsimony among the Crossodactylus species analyzed in the present study.
Figure S2 - Chromosomes of C. gaudichaudii and C. aeneus C-banded.

Associate Editor: Maria José de J. Silva

License information: This is an open-access article distributed under the terms of the Creative Commons Attribution License (type CC-BY), which permits unrestricted use, distribution and reproduction in any medium, provided the original article is properly cited. 